\title{
Correction to: Construction of genetic transformation system of Salix mongolica: in vitro leaf-based callus induction, adventitious buds differentiation, and plant regeneration
}

\author{
Qingjie Guan ${ }^{1} \cdot$ Mingliang He ${ }^{1} \cdot$ Haiyan $\mathrm{Ma}^{1} \cdot \mathrm{Xu} \mathrm{Liao}^{1} \cdot$ Zhenjuan Wang $^{1} \cdot$ Shenkui Liu ${ }^{1}$
}

Published online: 28 November 2018

C) Springer Nature B.V. 2018

\section{Correction to:}

Plant Cell, Tissue and Organ Culture (PCTOC)

(2018) 132:213-217

https://doi.org/10.1007/s11240-017-1265-9

There was an error in the second author's name in the original article. The name is correctly shown here.

\section{Shenkui Liu}

shenkuiliu@nefu.edu.cn

1 Key Laboratory of Saline-alkali Vegetation Ecology Restoration (SAVER), Ministry of Education, Alkali Soil Natural Environmental Science Center (ASNESC), Northeast Forestry University, No.26 hexing Road, Nangang District, Harbin 150040, China 